\author{
Szakács Tamás, Pokorádi László
}

\title{
PNEUMOBIL VEZÉRLÉSI RENDSZERÉNEK GRÁFVIZSGÁLATA
}

DOI: $10.32560 / \mathrm{rk} .2019 .1 .5$

\begin{abstract}
Az Aventics/Emerson cég, és jogelödei 2008 óta rendszeresen megszervezik a hazai és külföldi felsöoktatási intézmények diákjainak kiirt süritett levegövel hajtott pneumobilok versenyét. Ez a verseny 2019-re egy nemzetközileg is jelentös versennyé nötte ki magát. 2018-ban 9 ország több mint ötven csapata nevezett, melyböl a szigorú müszaki követelmények miatt csupán 38 csapat tudott a rajthoz állni. Az Óbudai Egyetem és jogelöde az elsö verseny óta folyamatosan 2-4 csapattal nevezett a versenyen, melyen a csapatoknak különbözö futamokon kell helytállniuk. Az egyik futam a jármü hatékonyságát teszi próbára, mivel a cél az egy palacknyi töltéssel megtehetö legnagyobb távolság elérése. A másik futamon a legnagyobb gyorsulás, és végsebesség elérése a feladat. A harmadikon pedig a jármü kezelhetösége, dinamikussága és a pilóta vezetési képessége a döntö. A változó elvárásoknak megfelelöen a különbözö futamokra eltérö motorvezérlési stratégiát kell kidolgozni, ami a motorvezérlés kialakitását nagyon összetett feladattá teszi. A komplex vezérlési stratégiák kifejlesztése rendszerszintü vizsgálatot igényel. A tanulmány egy ilyen vizsgálati módszert, a pneumobil vezérlésének gráf-vizsgálatát mutatja be.
\end{abstract}

Kulcsszavak: Jármü; pneumobil; vezérlés; gráf modellezés

\section{BEVEZETÉS}

Az Aventics/Emerson cég 2008 óta rendezi meg a nemzetközi pneumobil versenyt, melyen hazai, és külföldi felsőoktatási intézmények hallgatói vesznek részt. A versenyeken különböző futamokat (távolsági, ügyességi, és gyorsulási) rendeznek, melyek teljesítéséhez a járműveknek eltérő követelményeknek kell megfelelniük. Az évek során a verseny nagyon szorossá vált, az esélyek, eredmények kiegyenlítődtek. Azoknak a csapatoknak, akik versenyben akarnak maradni, megfelelő motorvezérlő-rendszert kell fejleszteniük, és azt optimalizálniuk.

Az egyes futamok megfelelő teljesítéséhez különböző vezérlési stratégiákra van szükség. A távolsági futamon a palackban tárolt gázenergiának utolsó cseppjét is mozgásenergiává kell alakítani. Az ügyességi futamon a jármű kezelhetőségén és a pilóta képességén kívül a jármü dinamikussága játszik fontos szerepet. A gyorsulási versenyen a folyamatosan, nagyobb sebességtartományban is leadott nyomaték az elvárás.

Integrált, komplexkapcsolatú rendszer, mint például egy pneumobil vezérlő rendszer, elemzése során azt diszkrét gráffal (vagy hálózattal) kell reprezentálni. Ez számos jármütechnikai (például elektromos, hidraulikus, szenzor) rendszer esetén megtehető.

Nagyméretü, lineáris rendszer gráf-reprezentációjának meghatározása után a gráfot jelképes értelemben „fel kell vágni” kisebb részgráfokra, majd a részgráfok egyenleteinek megoldása után az egyes részek megoldásait „össze kell kapcsolni” (ha szükséges, akár több lépésben is), ami az eredeti rendszer megoldásához vezet. A gráf modell egyrészt fontos állomás az eredeti, teljes rendszer egyenleteinek felállításában, másrészt a vágási eljárás megtervezéséhez nyújt segítséget.

A gráfelméletnek és mérnöki alkalmazásának kiterjedt matematikai és müszaki szakirodalma található. A technikai folyamatok leírásához szükséges gráfelméleti alapismeretek olvashatóak 
Broinstejn [1] könyvében, valamint Fazekas [2] egyetemi jegyzetében.

A gráfelmélet, mint matematikai apparátus, müszaki alkalmazására láthatunk példákat a Pokorádi [4], [5] és [6] publikációiban.

Péter tetszőleges méretü nemlineáris közúti közlekedési hálózatok modellezési lehetőségét vizsgálta speciális hálózati gráffal, amelyben a gráf csúcsai általánosított szakaszok, a gráf élei pedig a csúcsok közötti kooperációt leíró dinamikus relációk [3].

Munkánk célja, a Pokorádi [4] által kifejlesztett algoritmus alkalmazásának bemutatása az Óbudai Egyetem PowAir pneumobil csapatának Ignite nevü jármüvének vezérlésén.

A tanulmány az alábbi fejezetekből áll: A 2. fejezet a vizsgált vezérlörendszer mutatja be. A 3. fejezetben az egyes üzemmódokhoz tartozó elérhetőségi mátrixok meghatározásának módszerét mutatja be. A 4. fejezetben a szerzők a gráf-vizsgálat eredményeiből levonható szakmai következtetéseket írják le. Végül, az 5. fejezetben a szerzők összegzik a tanulmányt.

\section{A VEZÉRLŐ RENDSZER}

A motoregység meghajtásához egy Ø 100 mm-es 400 mm lökethosszú kettőslöketű pneumatikus munkahengert $\{1.1\}$ használunk.

A hengerek ki- és befelé mozgását kettő CD12 5/3-as elektromos müködtetésű, elővezérelt, középhelyzetben zárt útváltó szelep $\{9.2\}$ vezérli, melyek egy Texas Instruments által gyártott MSP430G2553, és TM4C123G mikrokontrollerekből, és a hozzá csatolt kapcsolóelektronikáról kapják a vezérléshez szükséges jelet.

Ezt a rendszert kiegészíti két darab CD12 monostabil 3/2 elektromos müködtetésü útváltó szelep $\{9.1\}$ ami a P1-es pufferek (4×13,38 1) levegőellátásáért és leszellőztetéséért felelnek.

A nyomásszabályzást az elektromos „fokozatmentesen beállítható üzemi nyomás” készletével \{15.1\} állítjuk, melynek fó részei: 1 db NL4-RGS nyomásszabályozó szelep, 1 db ED02 E/P nyomásszabályozó szelep.

Ezen kívül megtalálható egy CD04 monostabil 3/2 NO/NC pneumatikus vezérlésủ szelep $\{8.1\}$ ami az elővezérlőkör és a P2-es puffer $\{21\}$ levegőellátásáért felel kiegészítve egy rugós viszszacsapó szeleppel \{12.1\}. A rendszerben található érzékelők: 4 db PE5-ös nyomásmérő szenzor $\{6.3\}, 1 \mathrm{db}$ SM6-AL analóg útmérőszenzor $\{6.1\}$.

Távolsági üzemmód esetén a táplevegő lezárása után az egyik $5 / 3$ szelep zárva van, ilyenkor a másik 5/3 szelepeken át tud leszellőzni a rendszer, miközben a henger a mozgását végzi. A rendszerhez tartozik a palack után helyezett reduktor, majd egy vészstop kör $\{14.1\}$, mely segítségével lezárható és légteleníthető a teljes rendszer.

A járművön található nyomatékváltó vezérlését két Ø16/25-ös kétoldali működtetésű kiegészítő munkahenger $\{3.1\}$ végzi. Ezeket két TC08 2×3/2 NC/NC elektromos müködtetésű szelep $\{9.3\}$ egyesével müködteti. 


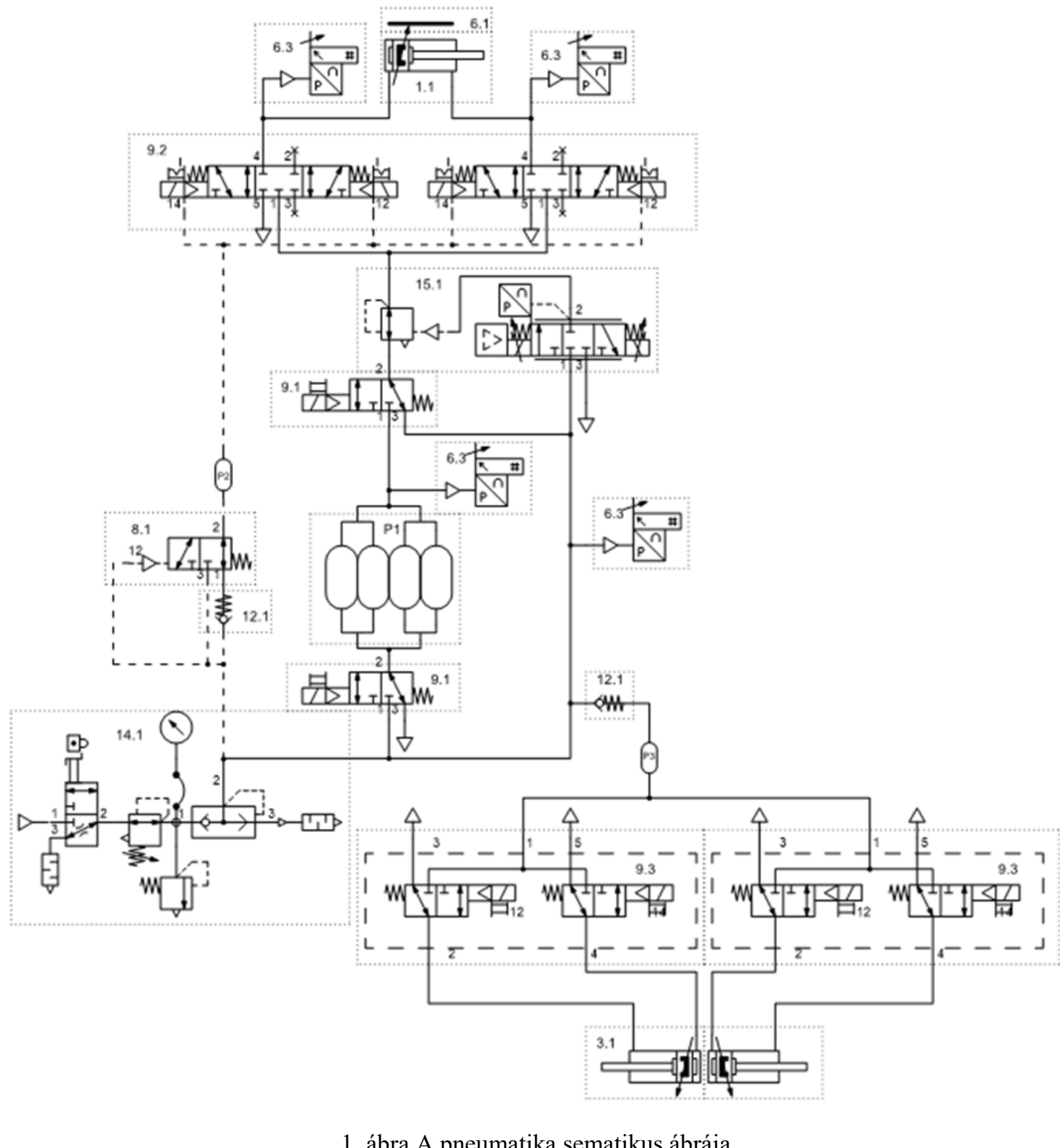

A vezérlés több üzemmódot tartalmaz.

A verseny 3 futamára különbözö üzemmódokat fejlesztettünk ki. Ezek a futamok:

$\rightarrow$ távolsági;

^ ügyességi;

$\uparrow$ és gyorsulási.

A három futamra tervezett üzemmódon kívül van még egy hiba- és egy vészstop-üzemmód is. A vészstop üzemmódon kívül a gázpedálszenzor minden üzemmódban szerepet játszik. Az útszenzor a hiba üzemmód, és a vészstop üzemmód kivételével mindig aktív. A további szenzorok, aktuátorok, és funkciók leírása a következő alfejezetekben találhatók. 


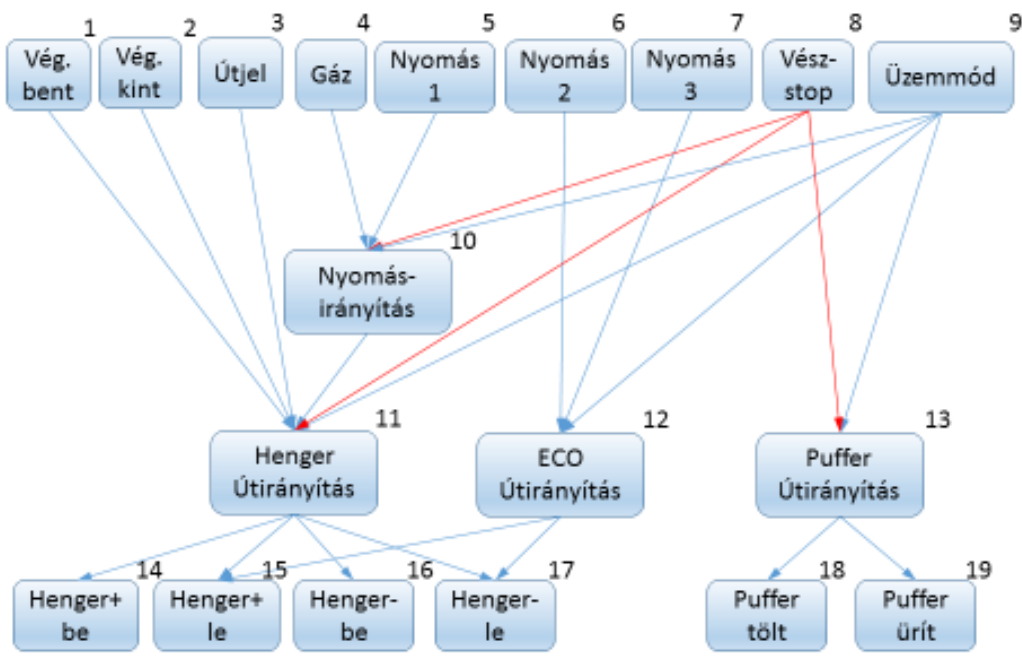

2. ábra A vezérlés sémája

\section{Távolsági üzemmód}

A távolsági futam célja, hogy egy 10 literes palack 200 bar nyomású nitrogénnel a jármü a legnagyobb távolságot tegye meg. ebben az üzemmódban a palackban tárolt energiát a legnagyobb mértékben kell mozgásra fordítani. A verseny során a teljesített körök sebességátlaga nem lehet kevesebb, mint $15 \mathrm{~km} / \mathrm{h}$.

Ezt az üzemmódot ECO-módnak is nevezzük. Ezen a futamon az üzemmódkapcsoló ECO állásban van.

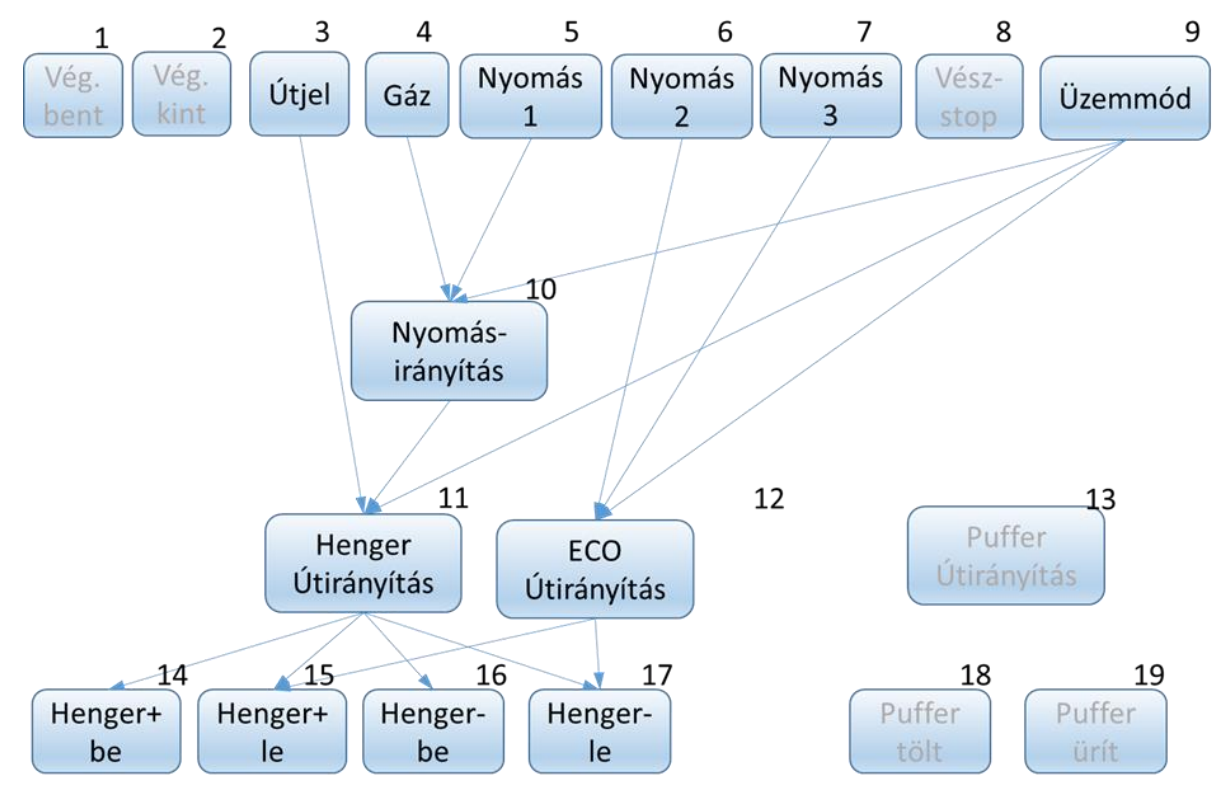

3. ábra Távolsági üzemmód

Ebben az üzemmódban mindhárom nyomásszenzornak szerepe van. nyomás 1 a gázpedálállással együtt a rendszernyomást, nyomás 2 és 3 az ECO üzemmód kiexpandálás-végi nyomásait befolyásolja.

Mint már említettük, tervezési követelmény, hogy technikai (anyagi és rendszer) okból bekövetkező baleseti kockázat nem haladhatja meg az általános baleseti hányados 50\%-át. 


\section{Ügyességi futam üzemmód}

Az ügyességi üzemmód abban különbözik a távolságitól, hogy ebben az esetben nincs ECO mód, ezért a nyomás 2 és 3 szenzoroknak nincs szerepük, továbbá nincs szerepe az expanzió vezérlésnek sem.

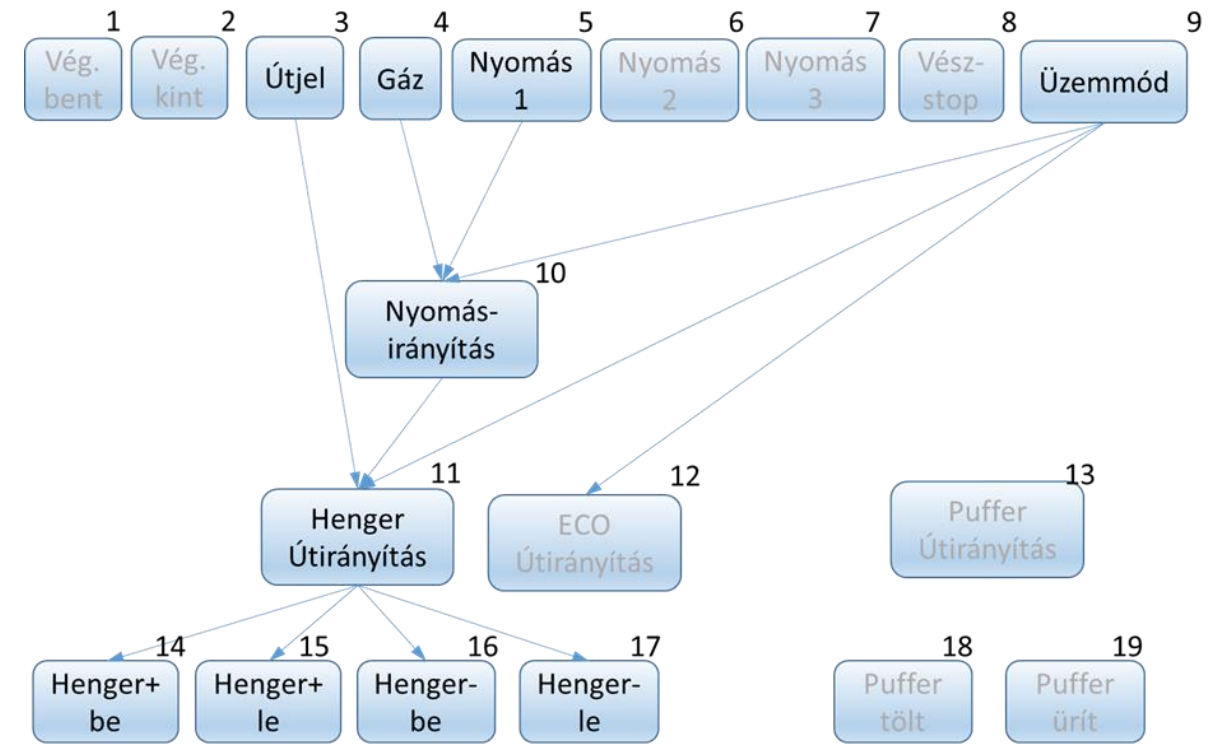

4. ábra Ügyességi futam üzemmód

Mint már említettük, tervezési követelmény, hogy technikai (anyagi és rendszer) okból bekövetkező baleseti kockázat nem haladhatja meg az általános baleseti hányados 50\%-át.

\section{Gyorsulási futam üzemmód}

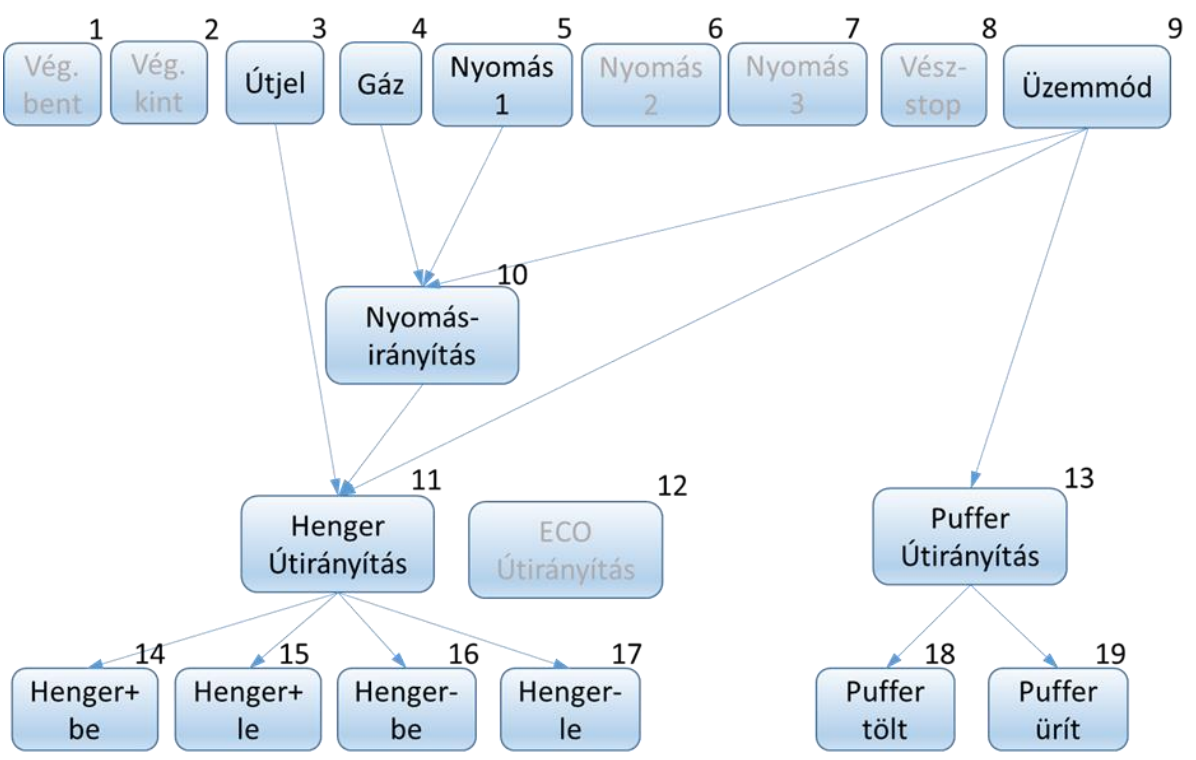

5. ábra Gyorsulási futam üzemmód

A gyorsulási üzemmódban a rendszer levegőellátását a pufferekbe előzetesen betárolt légmenynyiség is támogatja. nincs ECO üzemmód, viszont a hengerek vezérlése az ECO, és a gyorsulási üzemhez képest módosult. A hengerek ellenkamrája a dugattyú végpontjának elérése előtt már töltést kapnak, így a henger megfordítása rövidebb idő alatt zajlik le. 


\section{Vész-stop üzemmód}

A vészstop aktiválása esetén a vezérlésnek fel kel oldania a munkahenger reteszelését, le kell ürítenie a puffer tartályt, és meg kell szüntetnie a rendszernyomást.

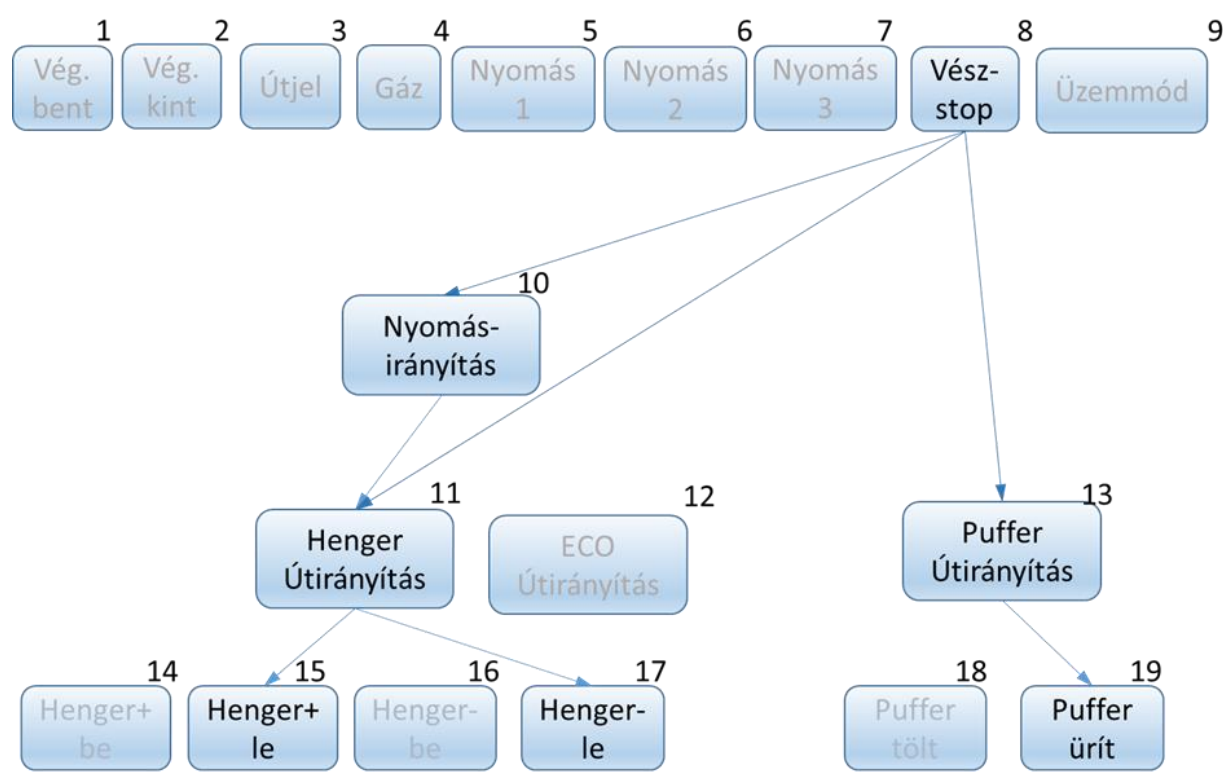

6. ábra Vész-stop üzemmód

\section{Hibaüzem mód}

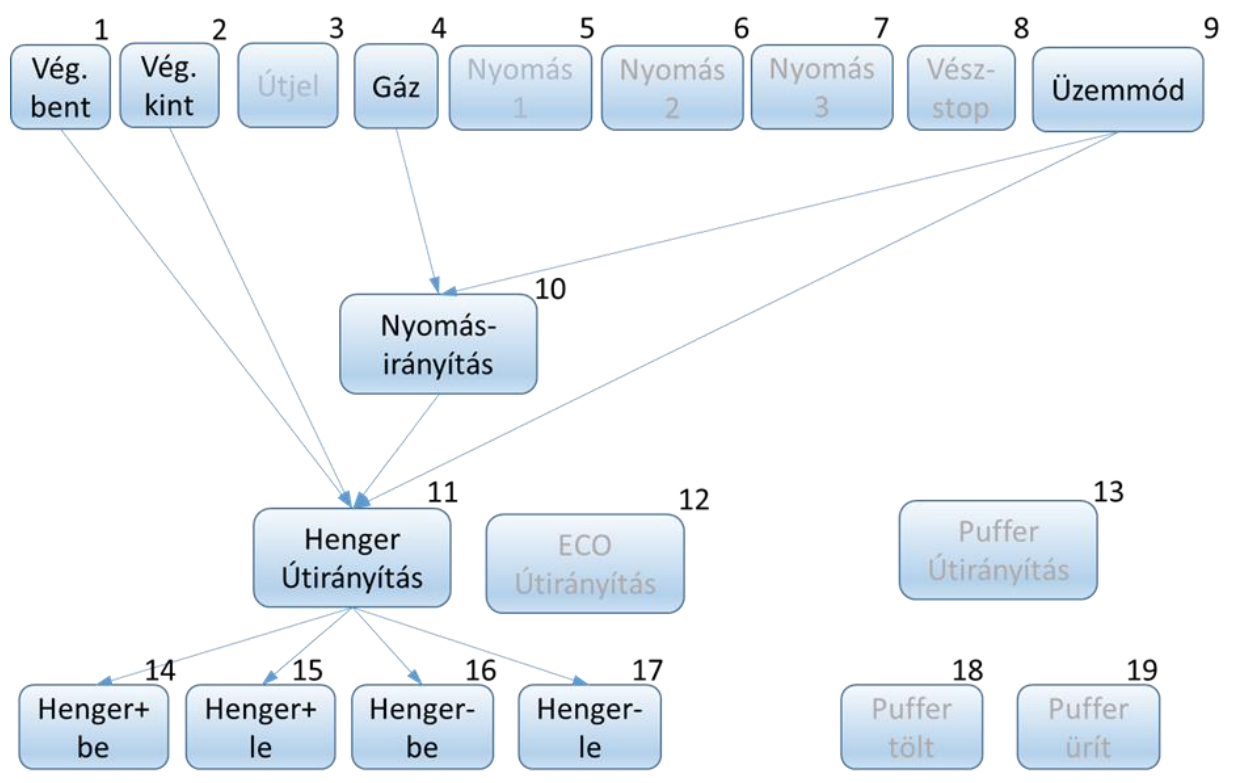

7. ábra Hibaüzemmód

Hiba üzemmódban a rendszervezérlés a jármű mozgásához szükséges alapfunkciókat látja csak el. A hengerpozíció érzékelését a lineáris útjel adó helyett 2 darab reed-relés végállás kapcsoló biztosítja. Ezen kívül a gázpedálszenzor ad jelet, a vezérlés pedig ECO, puffer, és minden egyéb segédfunkciók nélkül egy alapvezérlés üzemben dolgozik. 


\section{A RENDSZER GRÁFVIZSGÁLATA}

A gráf olyan alakzat, amely $\boldsymbol{P}$ pontokból és bizonyos pontpárokat összekötő $\boldsymbol{E}$ élekből áll. Matematikai megfogalmazásban a $G(\boldsymbol{P} ; \boldsymbol{E} ; f)$, ahol $f$ az illeszkedési leképezés [1], [2].

Irányított gráfról akkor beszélünk, ha az élek végpontjainak sorrendjére is tekintettel vagyunk. Ha nem determinált az élek végpontjainak sorrendje, a gráfot irányítatlannak nevezzük.

A gráfokat általában grafikusan ábrázoljuk. Egy másik ábrázolási, leírási mód a belőlük képezhető különböző mátrixok alkalmazása. A gráf szögpontjai közti kapcsolatokat az úgynevezett csúcs- (szomszédossági-, vagy adjacencia-) mátrixszal lehet táblázatosan megadni. Irányított gráf esetén az $\mathbf{A}$ mátrix $i$-edik sor $j$-edik elemének $a_{i j}$ értéke a $p_{i}$ szögpontból induló és a $p_{j}$ végpontú élek számát jelöli, azaz:

$$
s_{i j}=\left\{\begin{array}{ll}
1, & \text { ha a } p_{i} \text {-csúcsból a } p_{j} \text { szögpontba vezet él } \\
0, & \text { ha nem }
\end{array} .\right.
$$

\section{Az elérhetőségi mátrix meghatározása}

Az A szomszédossági mátrix $\mathbf{A}_{k}$-val jelölt

$$
\mathbf{A}_{k}=\mathbf{A}^{k}
$$

$k$-adik hatványmátrixának elemei azt mutatják meg, hogy $k$ lépésben az $i$-edik szögpontból a $j$ edikbe hány egymástól - a fenti értelmezés szerint - független úton lehet eljutni

A hatványmátrixok

$$
\mathbf{H}_{k}=\sum_{n=1}^{k} \mathbf{A}^{n}
$$

összegezésével kapott $\mathbf{H}_{k}$ összegmátrix elemei azt adják meg, hogy legfeljebb $k$ lépésben az $i$ edik szögpontból a j-edikbe hány - egymástól független - úton lehet eljutni.

Képezzünk a $\mathbf{H}_{k}$ mátrixokból $\mathbf{S}_{k}$ jelü mátrixot az alábbi függvény szerint:

$$
\mathbf{S}_{k}=\operatorname{sign} \quad \mathbf{H}_{k} \quad s_{i j}^{[k]}=\operatorname{sign} h_{i j}^{[k]},
$$

ahol:

$$
\text { sign } \eta=\left\{\begin{aligned}
1, & \text { ha } \eta>0 \\
0, & \text { ha } \eta=0 \\
-1, & \text { ha } \eta<0
\end{aligned}\right.
$$

és nevezzük el ezeket a $\mathbf{H}_{k}$ mátrix szignum mátrixának, melynek elemei azt adják meg, hogy legfeljebb $k$ lépésben a gráf $p_{i}$ szögpontjából el lehet-e jutni a j-edik szögpontjába - az (1) egyenlettel megadott elérhetőségi mátrixszal analóg módon - azaz:

$$
s_{i j}^{[k]}= \begin{cases}1, & \text { ha a } p_{i} \text {-csúcsból a } p_{j} \text { szögpont maximum } k \text { lépésben elérhető } \\ 0, & \text { ha nem }\end{cases}
$$


Egy $m$ szögpontból álló gráfban a leghosszabb lehetséges él sorozat maximum $m$ élből állhat, mely - a kiindulási és a vég szögpont kivételével - minden hozzá tartozó szögpontot csak egyszer érint - azaz a lehetséges leghosszabb kör, vagy pálya.

$\mathrm{Ha}$

$$
\mathbf{A}^{k}=\mathbf{N}
$$

ahol $\mathbf{N}$ a zéró (null) mátrix, a gráf leghosszabb útjának hossza $k-1$, azaz a gráfban nem található $k$-hosszúságú, valamint annál hosszabb út.

$\mathrm{Ha}$

$$
\mathbf{S}_{k}=\mathbf{J}
$$

ahol J az úgynevezett csupa-egyes mátrix, akkor a gráf minden szögpontja elérhető mindegyik szögpontból.

A fenti három feltétel figyelembevételével határozható meg az elérhetőségi mátrix.

Az elérhetőségi mátrix ismeretében az

$$
\mathbf{e}=\left[e_{k}\right] \quad e_{k}=\sum_{j=1}^{m} z_{j k}
$$

kitettség vektor, illetve az

$$
\mathbf{i}=\left[i_{k}\right] \quad i_{k}=\sum_{j=l}^{m} z_{k j}
$$

hatásvektor meghatározható.

Az e kitettség vektor azt mutatja meg, hogy a rendszer mely elemére hat a többi elem közül a legtöbb. Azaz az adott szögpont (értsd rendszerelem, vagy folyamatállapot) milyen mértékben érzékeny, kitett a többi rendszerelemben, vagy folyamatállapotban fellépő esetleges meghibásodásra, problémára.

Az i hatás vektor azt szemlélteti, hogy az adott rendszerelem meghibásodása mennyi más rendszerelem müködésére hat.

A fenti három feltétel figyelembevételével határozható meg az elérhetőségi meghatározásának folyamata, amit a 8. ábrán látható folyamatábra szemléltet, kiegészítve az alábbi elemzésekkel.

A röviden bemutatott módszert alkalmaztuk a pneumobil vezérlési rendszerének elemzésére. A következőkben a különböző, előzőekben leírt üzemmódokhoz tartózó szomszédossági és elérhetőségi mátrixokat, valamint kitettségi-, és hatásvektorokat adjuk meg. Ezt követően azokat szakmai szempontokból értékeljük.

A 2. fejezetben bemutatott öt üzemmód együttes elemzésére bevezettük az

$$
\begin{gathered}
\mathbf{e}_{\Sigma}=\mathbf{e}_{\mathrm{ECO}}+\mathbf{e}_{\mathrm{N}}+\mathbf{e}_{\mathrm{P}}+\mathbf{e}_{\mathrm{m}}+\mathbf{e}_{\mathrm{em}} \\
\mathbf{i}_{\Sigma}=\mathbf{i}_{\mathrm{ECO}}+\mathbf{i}_{\mathrm{N}}+\mathbf{i}_{\mathrm{P}}+\mathbf{i}_{\mathrm{m}}+\mathbf{i}_{\mathrm{em}}
\end{gathered}
$$

összegzett kitettség és összegzett hatásvektorokat. 


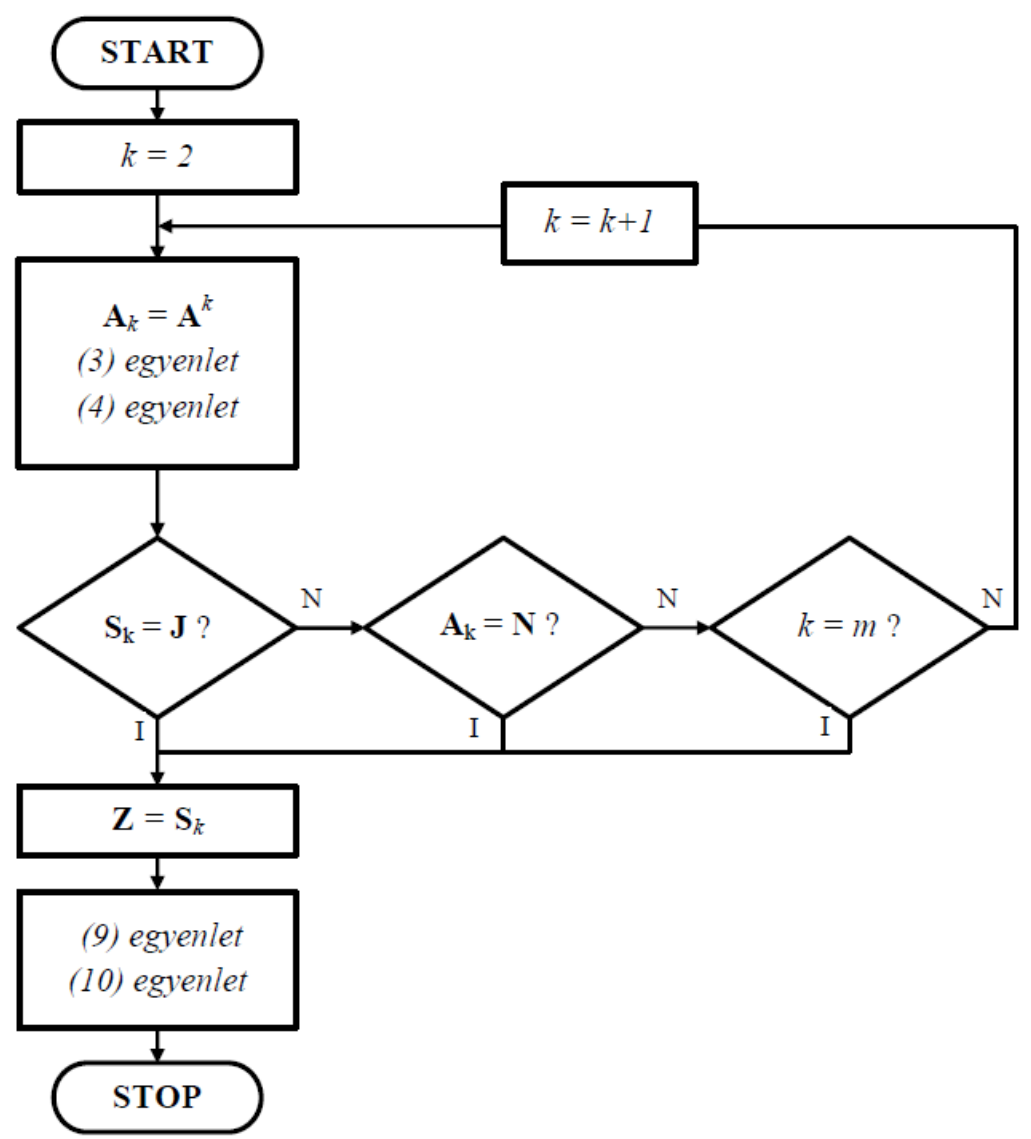

8. ábra A gráf-modell elemzés folyamatábrája

Távolsági futam üzemmód

$$
\mathbf{A}_{\mathrm{ECO}}=\left[\begin{array}{lllllllllllllllllll}
0 & 0 & 0 & 0 & 0 & 0 & 0 & 0 & 0 & 0 & 0 & 0 & 0 & 0 & 0 & 0 & 0 & 0 & 0 \\
0 & 0 & 0 & 0 & 0 & 0 & 0 & 0 & 0 & 0 & 0 & 0 & 0 & 0 & 0 & 0 & 0 & 0 & 0 \\
0 & 0 & 0 & 0 & 0 & 0 & 0 & 0 & 0 & 0 & 1 & 0 & 0 & 0 & 0 & 0 & 0 & 0 & 0 \\
0 & 0 & 0 & 0 & 0 & 0 & 0 & 0 & 0 & 1 & 0 & 0 & 0 & 0 & 0 & 0 & 0 & 0 & 0 \\
0 & 0 & 0 & 0 & 0 & 0 & 0 & 0 & 0 & 1 & 0 & 0 & 0 & 0 & 0 & 0 & 0 & 0 & 0 \\
0 & 0 & 0 & 0 & 0 & 0 & 0 & 0 & 0 & 0 & 0 & 1 & 0 & 0 & 0 & 0 & 0 & 0 & 0 \\
0 & 0 & 0 & 0 & 0 & 0 & 0 & 0 & 0 & 0 & 0 & 1 & 0 & 0 & 0 & 0 & 0 & 0 & 0 \\
0 & 0 & 0 & 0 & 0 & 0 & 0 & 0 & 0 & 0 & 0 & 0 & 0 & 0 & 0 & 0 & 0 & 0 & 0 \\
0 & 0 & 0 & 0 & 0 & 0 & 0 & 0 & 0 & 1 & 1 & 1 & 0 & 0 & 0 & 0 & 0 & 0 & 0 \\
0 & 0 & 0 & 0 & 0 & 0 & 0 & 0 & 0 & 0 & 1 & 0 & 0 & 0 & 0 & 0 & 0 & 0 & 0 \\
0 & 0 & 0 & 0 & 0 & 0 & 0 & 0 & 0 & 0 & 0 & 0 & 0 & 1 & 1 & 1 & 1 & 0 & 0 \\
0 & 0 & 0 & 0 & 0 & 0 & 0 & 0 & 0 & 0 & 0 & 0 & 0 & 0 & 1 & 0 & 1 & 0 & 0 \\
0 & 0 & 0 & 0 & 0 & 0 & 0 & 0 & 0 & 0 & 0 & 0 & 0 & 0 & 0 & 0 & 0 & 0 & 0 \\
0 & 0 & 0 & 0 & 0 & 0 & 0 & 0 & 0 & 0 & 0 & 0 & 0 & 0 & 0 & 0 & 0 & 0 & 0 \\
0 & 0 & 0 & 0 & 0 & 0 & 0 & 0 & 0 & 0 & 0 & 0 & 0 & 0 & 0 & 0 & 0 & 0 & 0 \\
0 & 0 & 0 & 0 & 0 & 0 & 0 & 0 & 0 & 0 & 0 & 0 & 0 & 0 & 0 & 0 & 0 & 0 & 0 \\
0 & 0 & 0 & 0 & 0 & 0 & 0 & 0 & 0 & 0 & 0 & 0 & 0 & 0 & 0 & 0 & 0 & 0 & 0 \\
0 & 0 & 0 & 0 & 0 & 0 & 0 & 0 & 0 & 0 & 0 & 0 & 0 & 0 & 0 & 0 & 0 & 0 & 0 \\
0 & 0 & 0 & 0 & 0 & 0 & 0 & 0 & 0 & 0 & 0 & 0 & 0 & 0 & 0 & 0 & 0 & 0 & 0
\end{array}\right]
$$




$$
\begin{aligned}
& \mathbf{Z}_{\mathrm{ECO}}=\left[\begin{array}{lllllllllllllllllll}
0 & 0 & 0 & 0 & 0 & 0 & 0 & 0 & 0 & 0 & 0 & 0 & 0 & 0 & 0 & 0 & 0 & 0 & 0 \\
0 & 0 & 0 & 0 & 0 & 0 & 0 & 0 & 0 & 0 & 0 & 0 & 0 & 0 & 0 & 0 & 0 & 0 & 0 \\
0 & 0 & 0 & 0 & 0 & 0 & 0 & 0 & 0 & 0 & 1 & 0 & 0 & 1 & 1 & 1 & 1 & 0 & 0 \\
0 & 0 & 0 & 0 & 0 & 0 & 0 & 0 & 0 & 1 & 1 & 0 & 0 & 1 & 1 & 1 & 1 & 0 & 0 \\
0 & 0 & 0 & 0 & 0 & 0 & 0 & 0 & 0 & 1 & 1 & 0 & 0 & 1 & 1 & 1 & 1 & 0 & 0 \\
0 & 0 & 0 & 0 & 0 & 0 & 0 & 0 & 0 & 0 & 0 & 1 & 0 & 0 & 1 & 0 & 1 & 0 & 0 \\
0 & 0 & 0 & 0 & 0 & 0 & 0 & 0 & 0 & 0 & 0 & 1 & 0 & 0 & 1 & 0 & 1 & 0 & 0 \\
0 & 0 & 0 & 0 & 0 & 0 & 0 & 0 & 0 & 0 & 0 & 0 & 0 & 0 & 0 & 0 & 0 & 0 & 0 \\
0 & 0 & 0 & 0 & 0 & 0 & 0 & 0 & 0 & 1 & 1 & 1 & 0 & 1 & 1 & 1 & 1 & 0 & 0 \\
0 & 0 & 0 & 0 & 0 & 0 & 0 & 0 & 0 & 0 & 1 & 0 & 0 & 1 & 1 & 1 & 1 & 0 & 0 \\
0 & 0 & 0 & 0 & 0 & 0 & 0 & 0 & 0 & 0 & 0 & 0 & 0 & 1 & 1 & 1 & 1 & 0 & 0 \\
0 & 0 & 0 & 0 & 0 & 0 & 0 & 0 & 0 & 0 & 0 & 0 & 0 & 0 & 1 & 0 & 1 & 0 & 0 \\
0 & 0 & 0 & 0 & 0 & 0 & 0 & 0 & 0 & 0 & 0 & 0 & 0 & 0 & 0 & 0 & 0 & 0 & 0 \\
0 & 0 & 0 & 0 & 0 & 0 & 0 & 0 & 0 & 0 & 0 & 0 & 0 & 0 & 0 & 0 & 0 & 0 & 0 \\
0 & 0 & 0 & 0 & 0 & 0 & 0 & 0 & 0 & 0 & 0 & 0 & 0 & 0 & 0 & 0 & 0 & 0 & 0 \\
0 & 0 & 0 & 0 & 0 & 0 & 0 & 0 & 0 & 0 & 0 & 0 & 0 & 0 & 0 & 0 & 0 & 0 & 0 \\
0 & 0 & 0 & 0 & 0 & 0 & 0 & 0 & 0 & 0 & 0 & 0 & 0 & 0 & 0 & 0 & 0 & 0 & 0 \\
0 & 0 & 0 & 0 & 0 & 0 & 0 & 0 & 0 & 0 & 0 & 0 & 0 & 0 & 0 & 0 & 0 & 0 & 0 \\
0 & 0 & 0 & 0 & 0 & 0 & 0 & 0 & 0 & 0 & 0 & 0 & 0 & 0 & 0 & 0 & 0 & 0 & 0
\end{array}\right] \\
& \mathbf{e}_{\mathrm{ECO}}^{\mathrm{T}}=\left[\begin{array}{lllllllllllllllllll}
0 & 0 & 0 & 0 & 0 & 0 & 0 & 0 & 0 & 3 & 5 & 3 & 0 & 0 & 6 & 9 & 9 & 0 & 0
\end{array}\right] \\
& \mathbf{i}_{\mathrm{ECO}}^{\mathrm{T}}=\left[\begin{array}{lllllllllllllllllll}
0 & 0 & 5 & 6 & 6 & 3 & 3 & 0 & 7 & 5 & 4 & 2 & 0 & 0 & 0 & 0 & 0 & 0 & 0
\end{array}\right]
\end{aligned}
$$

\section{Ügyességi futam üzemmód}

$$
\mathbf{A}_{\mathrm{N}}=\left[\begin{array}{lllllllllllllllllll}
0 & 0 & 0 & 0 & 0 & 0 & 0 & 0 & 0 & 0 & 0 & 0 & 0 & 0 & 0 & 0 & 0 & 0 & 0 \\
0 & 0 & 0 & 0 & 0 & 0 & 0 & 0 & 0 & 0 & 0 & 0 & 0 & 0 & 0 & 0 & 0 & 0 & 0 \\
0 & 0 & 0 & 0 & 0 & 0 & 0 & 0 & 0 & 0 & 1 & 0 & 0 & 0 & 0 & 0 & 0 & 0 & 0 \\
0 & 0 & 0 & 0 & 0 & 0 & 0 & 0 & 0 & 1 & 0 & 0 & 0 & 0 & 0 & 0 & 0 & 0 & 0 \\
0 & 0 & 0 & 0 & 0 & 0 & 0 & 0 & 0 & 1 & 0 & 0 & 0 & 0 & 0 & 0 & 0 & 0 & 0 \\
0 & 0 & 0 & 0 & 0 & 0 & 0 & 0 & 0 & 0 & 0 & 0 & 0 & 0 & 0 & 0 & 0 & 0 & 0 \\
0 & 0 & 0 & 0 & 0 & 0 & 0 & 0 & 0 & 0 & 0 & 0 & 0 & 0 & 0 & 0 & 0 & 0 & 0 \\
0 & 0 & 0 & 0 & 0 & 0 & 0 & 0 & 0 & 0 & 0 & 0 & 0 & 0 & 0 & 0 & 0 & 0 & 0 \\
0 & 0 & 0 & 0 & 0 & 0 & 0 & 0 & 0 & 1 & 1 & 1 & 0 & 0 & 0 & 0 & 0 & 0 & 0 \\
0 & 0 & 0 & 0 & 0 & 0 & 0 & 0 & 0 & 0 & 1 & 0 & 0 & 0 & 0 & 0 & 0 & 0 & 0 \\
0 & 0 & 0 & 0 & 0 & 0 & 0 & 0 & 0 & 0 & 0 & 0 & 0 & 1 & 1 & 1 & 1 & 0 & 0 \\
0 & 0 & 0 & 0 & 0 & 0 & 0 & 0 & 0 & 0 & 0 & 0 & 0 & 0 & 0 & 0 & 0 & 0 & 0 \\
0 & 0 & 0 & 0 & 0 & 0 & 0 & 0 & 0 & 0 & 0 & 0 & 0 & 0 & 0 & 0 & 0 & 0 & 0 \\
0 & 0 & 0 & 0 & 0 & 0 & 0 & 0 & 0 & 0 & 0 & 0 & 0 & 0 & 0 & 0 & 0 & 0 & 0 \\
0 & 0 & 0 & 0 & 0 & 0 & 0 & 0 & 0 & 0 & 0 & 0 & 0 & 0 & 0 & 0 & 0 & 0 & 0 \\
0 & 0 & 0 & 0 & 0 & 0 & 0 & 0 & 0 & 0 & 0 & 0 & 0 & 0 & 0 & 0 & 0 & 0 & 0 \\
0 & 0 & 0 & 0 & 0 & 0 & 0 & 0 & 0 & 0 & 0 & 0 & 0 & 0 & 0 & 0 & 0 & 0 & 0 \\
0 & 0 & 0 & 0 & 0 & 0 & 0 & 0 & 0 & 0 & 0 & 0 & 0 & 0 & 0 & 0 & 0 & 0 & 0 \\
0 & 0 & 0 & 0 & 0 & 0 & 0 & 0 & 0 & 0 & 0 & 0 & 0 & 0 & 0 & 0 & 0 & 0 & 0
\end{array}\right]
$$




$$
\mathbf{Z}_{\mathrm{N}}=\left[\begin{array}{lllllllllllllllllll}
0 & 0 & 0 & 0 & 0 & 0 & 0 & 0 & 0 & 0 & 0 & 0 & 0 & 0 & 0 & 0 & 0 & 0 & 0 \\
0 & 0 & 0 & 0 & 0 & 0 & 0 & 0 & 0 & 0 & 0 & 0 & 0 & 0 & 0 & 0 & 0 & 0 & 0 \\
0 & 0 & 0 & 0 & 0 & 0 & 0 & 0 & 0 & 0 & 1 & 0 & 0 & 1 & 1 & 1 & 1 & 0 & 0 \\
0 & 0 & 0 & 0 & 0 & 0 & 0 & 0 & 0 & 1 & 1 & 0 & 0 & 1 & 1 & 1 & 1 & 0 & 0 \\
0 & 0 & 0 & 0 & 0 & 0 & 0 & 0 & 0 & 1 & 1 & 0 & 0 & 1 & 1 & 1 & 1 & 0 & 0 \\
0 & 0 & 0 & 0 & 0 & 0 & 0 & 0 & 0 & 0 & 0 & 0 & 0 & 0 & 0 & 0 & 0 & 0 & 0 \\
0 & 0 & 0 & 0 & 0 & 0 & 0 & 0 & 0 & 0 & 0 & 0 & 0 & 0 & 0 & 0 & 0 & 0 & 0 \\
0 & 0 & 0 & 0 & 0 & 0 & 0 & 0 & 0 & 0 & 0 & 0 & 0 & 0 & 0 & 0 & 0 & 0 & 0 \\
0 & 0 & 0 & 0 & 0 & 0 & 0 & 0 & 0 & 1 & 1 & 1 & 0 & 1 & 1 & 1 & 1 & 0 & 0 \\
0 & 0 & 0 & 0 & 0 & 0 & 0 & 0 & 0 & 0 & 1 & 0 & 0 & 1 & 1 & 1 & 1 & 0 & 0 \\
0 & 0 & 0 & 0 & 0 & 0 & 0 & 0 & 0 & 0 & 0 & 0 & 0 & 1 & 1 & 1 & 1 & 0 & 0 \\
0 & 0 & 0 & 0 & 0 & 0 & 0 & 0 & 0 & 0 & 0 & 0 & 0 & 0 & 0 & 0 & 0 & 0 & 0 \\
0 & 0 & 0 & 0 & 0 & 0 & 0 & 0 & 0 & 0 & 0 & 0 & 0 & 0 & 0 & 0 & 0 & 0 & 0 \\
0 & 0 & 0 & 0 & 0 & 0 & 0 & 0 & 0 & 0 & 0 & 0 & 0 & 0 & 0 & 0 & 0 & 0 & 0 \\
0 & 0 & 0 & 0 & 0 & 0 & 0 & 0 & 0 & 0 & 0 & 0 & 0 & 0 & 0 & 0 & 0 & 0 & 0 \\
\mathbf{i}_{\mathrm{P}}^{\mathrm{T}} & =\left[\begin{array}{llllllllllllllllllllllllllll}
0 & 0 & 0 & 0 & 0 & 0 & 0 & 0 & 0 & 3 & 5 & 1 & 0 & 6 & 6 & 6 & 6 & 0 & 0
\end{array}\right] \\
0 & 0 & 5 & 6 & 6 & 0 & 0 & 0 & 7 & 5 & 4 & 0 & 0 & 0 & 0 & 0 & 0 & 0 & 0
\end{array}\right]
$$

\section{Gyorsulási futam üzemmód}

$$
\mathbf{A}_{P}=\left[\begin{array}{lllllllllllllllllll}
0 & 0 & 0 & 0 & 0 & 0 & 0 & 0 & 0 & 0 & 0 & 0 & 0 & 0 & 0 & 0 & 0 & 0 & 0 \\
0 & 0 & 0 & 0 & 0 & 0 & 0 & 0 & 0 & 0 & 0 & 0 & 0 & 0 & 0 & 0 & 0 & 0 & 0 \\
0 & 0 & 0 & 0 & 0 & 0 & 0 & 0 & 0 & 0 & 1 & 0 & 0 & 0 & 0 & 0 & 0 & 0 & 0 \\
0 & 0 & 0 & 0 & 0 & 0 & 0 & 0 & 0 & 1 & 0 & 0 & 0 & 0 & 0 & 0 & 0 & 0 & 0 \\
0 & 0 & 0 & 0 & 0 & 0 & 0 & 0 & 0 & 1 & 0 & 0 & 0 & 0 & 0 & 0 & 0 & 0 & 0 \\
0 & 0 & 0 & 0 & 0 & 0 & 0 & 0 & 0 & 0 & 0 & 0 & 0 & 0 & 0 & 0 & 0 & 0 & 0 \\
0 & 0 & 0 & 0 & 0 & 0 & 0 & 0 & 0 & 0 & 0 & 0 & 0 & 0 & 0 & 0 & 0 & 0 & 0 \\
0 & 0 & 0 & 0 & 0 & 0 & 0 & 0 & 0 & 0 & 0 & 0 & 0 & 0 & 0 & 0 & 0 & 0 & 0 \\
0 & 0 & 0 & 0 & 0 & 0 & 0 & 0 & 0 & 1 & 1 & 0 & 0 & 0 & 0 & 0 & 0 & 0 & 0 \\
0 & 0 & 0 & 0 & 0 & 0 & 0 & 0 & 0 & 0 & 1 & 0 & 0 & 0 & 0 & 0 & 0 & 0 & 0 \\
0 & 0 & 0 & 0 & 0 & 0 & 0 & 0 & 0 & 0 & 0 & 0 & 0 & 1 & 1 & 1 & 1 & 0 & 0 \\
0 & 0 & 0 & 0 & 0 & 0 & 0 & 0 & 0 & 0 & 0 & 0 & 0 & 0 & 0 & 0 & 0 & 0 & 0 \\
0 & 0 & 0 & 0 & 0 & 0 & 0 & 0 & 0 & 0 & 0 & 0 & 0 & 0 & 0 & 0 & 0 & 1 & 1 \\
0 & 0 & 0 & 0 & 0 & 0 & 0 & 0 & 0 & 0 & 0 & 0 & 0 & 0 & 0 & 0 & 0 & 0 & 0 \\
0 & 0 & 0 & 0 & 0 & 0 & 0 & 0 & 0 & 0 & 0 & 0 & 0 & 0 & 0 & 0 & 0 & 0 & 0 \\
0 & 0 & 0 & 0 & 0 & 0 & 0 & 0 & 0 & 0 & 0 & 0 & 0 & 0 & 0 & 0 & 0 & 0 & 0 \\
0 & 0 & 0 & 0 & 0 & 0 & 0 & 0 & 0 & 0 & 0 & 0 & 0 & 0 & 0 & 0 & 0 & 0 & 0 \\
0 & 0 & 0 & 0 & 0 & 0 & 0 & 0 & 0 & 0 & 0 & 0 & 0 & 0 & 0 & 0 & 0 & 0 & 0 \\
0 & 0 & 0 & 0 & 0 & 0 & 0 & 0 & 0 & 0 & 0 & 0 & 0 & 0 & 0 & 0 & 0 & 0 & 0
\end{array}\right]
$$




$$
\mathbf{Z}_{\mathrm{P}}=\left[\begin{array}{lllllllllllllllllll}
0 & 0 & 0 & 0 & 0 & 0 & 0 & 0 & 0 & 0 & 0 & 0 & 0 & 0 & 0 & 0 & 0 & 0 & 0 \\
0 & 0 & 0 & 0 & 0 & 0 & 0 & 0 & 0 & 0 & 0 & 0 & 0 & 0 & 0 & 0 & 0 & 0 & 0 \\
0 & 0 & 0 & 0 & 0 & 0 & 0 & 0 & 0 & 0 & 1 & 0 & 0 & 1 & 1 & 1 & 1 & 0 & 0 \\
0 & 0 & 0 & 0 & 0 & 0 & 0 & 0 & 0 & 1 & 1 & 0 & 0 & 1 & 1 & 1 & 1 & 0 & 0 \\
0 & 0 & 0 & 0 & 0 & 0 & 0 & 0 & 0 & 1 & 1 & 0 & 0 & 1 & 1 & 1 & 1 & 0 & 0 \\
0 & 0 & 0 & 0 & 0 & 0 & 0 & 0 & 0 & 0 & 0 & 0 & 0 & 0 & 0 & 0 & 0 & 0 & 0 \\
0 & 0 & 0 & 0 & 0 & 0 & 0 & 0 & 0 & 0 & 0 & 0 & 0 & 0 & 0 & 0 & 0 & 0 & 0 \\
0 & 0 & 0 & 0 & 0 & 0 & 0 & 0 & 0 & 0 & 0 & 0 & 0 & 0 & 0 & 0 & 0 & 0 & 0 \\
0 & 0 & 0 & 0 & 0 & 0 & 0 & 0 & 0 & 1 & 1 & 0 & 1 & 1 & 1 & 1 & 1 & 0 & 0 \\
0 & 0 & 0 & 0 & 0 & 0 & 0 & 0 & 0 & 0 & 1 & 0 & 0 & 1 & 1 & 1 & 1 & 0 & 0 \\
0 & 0 & 0 & 0 & 0 & 0 & 0 & 0 & 0 & 0 & 0 & 0 & 0 & 1 & 1 & 1 & 1 & 0 & 0 \\
0 & 0 & 0 & 0 & 0 & 0 & 0 & 0 & 0 & 0 & 0 & 0 & 0 & 0 & 0 & 0 & 0 & 0 & 0 \\
0 & 0 & 0 & 0 & 0 & 0 & 0 & 0 & 0 & 0 & 0 & 0 & 0 & 0 & 0 & 0 & 0 & 1 & 1 \\
0 & 0 & 0 & 0 & 0 & 0 & 0 & 0 & 0 & 0 & 0 & 0 & 0 & 0 & 0 & 0 & 0 & 0 & 0 \\
0 & 0 & 0 & 0 & 0 & 0 & 0 & 0 & 0 & 0 & 0 & 0 & 0 & 0 & 0 & 0 & 0 & 0 & 0 \\
0 & 0 & 0 & 0 & 0 & 0 & 0 & 0 & 0 & 0 & 0 & 0 & 0 & 0 & 0 & 0 & 0 & 0 & 0 \\
0 & 0 & 0 & 0 & 0 & 0 & 0 & 0 & 0 & 0 & 0 & 0 & 0 & 0 & 0 & 0 & 0 & 0 & 0 \\
0 & 0 & 0 & 0 & 0 & 0 & 0 & 0 & 0 & 0 & 0 & 0 & 0 & 0 & 0 & 0 & 0 & 0 & 0 \\
0 & 0 & 0 & 0 & 0 & 0 & 0 & 0 & 0 & 0 & 0 & 0 & 0 & 0 & 0 & 0 & 0 & 0 & 0
\end{array}\right]
$$

Vész-stop üzemmód

$$
\mathbf{A}_{\mathrm{em}}=\left[\begin{array}{lllllllllllllllllll}
0 & 0 & 0 & 0 & 0 & 0 & 0 & 0 & 0 & 0 & 0 & 0 & 0 & 0 & 0 & 0 & 0 & 0 & 0 \\
0 & 0 & 0 & 0 & 0 & 0 & 0 & 0 & 0 & 0 & 0 & 0 & 0 & 0 & 0 & 0 & 0 & 0 & 0 \\
0 & 0 & 0 & 0 & 0 & 0 & 0 & 0 & 0 & 0 & 0 & 0 & 0 & 0 & 0 & 0 & 0 & 0 & 0 \\
0 & 0 & 0 & 0 & 0 & 0 & 0 & 0 & 0 & 0 & 0 & 0 & 0 & 0 & 0 & 0 & 0 & 0 & 0 \\
0 & 0 & 0 & 0 & 0 & 0 & 0 & 0 & 0 & 0 & 0 & 0 & 0 & 0 & 0 & 0 & 0 & 0 & 0 \\
0 & 0 & 0 & 0 & 0 & 0 & 0 & 0 & 0 & 0 & 0 & 0 & 0 & 0 & 0 & 0 & 0 & 0 & 0 \\
0 & 0 & 0 & 0 & 0 & 0 & 0 & 0 & 0 & 0 & 0 & 0 & 0 & 0 & 0 & 0 & 0 & 0 & 0 \\
0 & 0 & 0 & 0 & 0 & 0 & 0 & 0 & 0 & 1 & 1 & 0 & 1 & 0 & 0 & 0 & 0 & 0 & 0 \\
0 & 0 & 0 & 0 & 0 & 0 & 0 & 0 & 0 & 0 & 0 & 0 & 0 & 0 & 0 & 0 & 0 & 0 & 0 \\
0 & 0 & 0 & 0 & 0 & 0 & 0 & 0 & 0 & 0 & 1 & 0 & 0 & 0 & 0 & 0 & 0 & 0 & 0 \\
0 & 0 & 0 & 0 & 0 & 0 & 0 & 0 & 0 & 0 & 0 & 0 & 0 & 0 & 1 & 0 & 1 & 0 & 0 \\
0 & 0 & 0 & 0 & 0 & 0 & 0 & 0 & 0 & 0 & 0 & 0 & 0 & 0 & 0 & 0 & 0 & 0 & 0 \\
0 & 0 & 0 & 0 & 0 & 0 & 0 & 0 & 0 & 0 & 0 & 0 & 0 & 0 & 0 & 0 & 0 & 0 & 1 \\
0 & 0 & 0 & 0 & 0 & 0 & 0 & 0 & 0 & 0 & 0 & 0 & 0 & 0 & 0 & 0 & 0 & 0 & 0 \\
0 & 0 & 0 & 0 & 0 & 0 & 0 & 0 & 0 & 0 & 0 & 0 & 0 & 0 & 0 & 0 & 0 & 0 & 0 \\
0 & 0 & 0 & 0 & 0 & 0 & 0 & 0 & 0 & 0 & 0 & 0 & 0 & 0 & 0 & 0 & 0 & 0 & 0 \\
0 & 0 & 0 & 0 & 0 & 0 & 0 & 0 & 0 & 0 & 0 & 0 & 0 & 0 & 0 & 0 & 0 & 0 & 0 \\
0 & 0 & 0 & 0 & 0 & 0 & 0 & 0 & 0 & 0 & 0 & 0 & 0 & 0 & 0 & 0 & 0 & 0 & 0 \\
0 & 0 & 0 & 0 & 0 & 0 & 0 & 0 & 0 & 0 & 0 & 0 & 0 & 0 & 0 & 0 & 0 & 0 & 0
\end{array}\right]
$$




$$
\mathbf{Z}_{\mathrm{em}}=\left[\begin{array}{lllllllllllllllllll}
0 & 0 & 0 & 0 & 0 & 0 & 0 & 0 & 0 & 0 & 0 & 0 & 0 & 0 & 0 & 0 & 0 & 0 & 0 \\
0 & 0 & 0 & 0 & 0 & 0 & 0 & 0 & 0 & 0 & 0 & 0 & 0 & 0 & 0 & 0 & 0 & 0 & 0 \\
0 & 0 & 0 & 0 & 0 & 0 & 0 & 0 & 0 & 0 & 0 & 0 & 0 & 0 & 0 & 0 & 0 & 0 & 0 \\
0 & 0 & 0 & 0 & 0 & 0 & 0 & 0 & 0 & 0 & 0 & 0 & 0 & 0 & 0 & 0 & 0 & 0 & 0 \\
0 & 0 & 0 & 0 & 0 & 0 & 0 & 0 & 0 & 0 & 0 & 0 & 0 & 0 & 0 & 0 & 0 & 0 & 0 \\
0 & 0 & 0 & 0 & 0 & 0 & 0 & 0 & 0 & 0 & 0 & 0 & 0 & 0 & 0 & 0 & 0 & 0 & 0 \\
0 & 0 & 0 & 0 & 0 & 0 & 0 & 0 & 0 & 0 & 0 & 0 & 0 & 0 & 0 & 0 & 0 & 0 & 0 \\
0 & 0 & 0 & 0 & 0 & 0 & 0 & 0 & 0 & 1 & 1 & 0 & 1 & 0 & 1 & 0 & 1 & 0 & 1 \\
0 & 0 & 0 & 0 & 0 & 0 & 0 & 0 & 0 & 0 & 0 & 0 & 0 & 0 & 0 & 0 & 0 & 0 & 0 \\
0 & 0 & 0 & 0 & 0 & 0 & 0 & 0 & 0 & 0 & 1 & 0 & 0 & 0 & 1 & 0 & 1 & 0 & 0 \\
0 & 0 & 0 & 0 & 0 & 0 & 0 & 0 & 0 & 0 & 0 & 0 & 0 & 0 & 1 & 0 & 1 & 0 & 0 \\
0 & 0 & 0 & 0 & 0 & 0 & 0 & 0 & 0 & 0 & 0 & 0 & 0 & 0 & 0 & 0 & 0 & 0 & 0 \\
0 & 0 & 0 & 0 & 0 & 0 & 0 & 0 & 0 & 0 & 0 & 0 & 0 & 0 & 0 & 0 & 0 & 0 & 0 \\
0 & 0 & 0 & 0 & 0 & 0 & 0 & 0 & 0 & 0 & 0 & 0 & 0 & 0 & 0 & 0 & 0 & 0 & 0 \\
0 & 0 & 0 & 0 & 0 & 0 & 0 & 0 & 0 & 0 & 0 & 0 & 0 & 0 & 0 & 0 & 0 & 0 & 0 \\
0 & 0 & 0 & 0 & 0 & 0 & 0 & 0 & 0 & 0 & 0 & 0 & 0 & 0 & 0 & 0 & 0 & 0 & 0 \\
0 & 0 & 0 & 0 & 0 & 0 & 0 & 0 & 0 & 0 & 0 & 0 & 0 & 0 & 0 & 0 & 0 & 0 & 0 \\
0 & 0 & 0 & 0 & 0 & 0 & 0 & 0 & 0 & 0 & 0 & 0 & 0 & 0 & 0 & 0 & 0 & 0 & 0 \\
0 & 0 & 0 & 0 & 0 & 0 & 0 & 0 & 0 & 0 & 0 & 0 & 0 & 0 & 0 & 0 & 0 & 0 & 0
\end{array}\right]
$$

\section{Hiba üzemmód}

$$
\mathbf{A}_{\mathrm{m}}=\left[\begin{array}{lllllllllllllllllll}
0 & 0 & 0 & 0 & 0 & 0 & 0 & 0 & 0 & 0 & 1 & 0 & 0 & 0 & 0 & 0 & 0 & 0 & 0 \\
0 & 0 & 0 & 0 & 0 & 0 & 0 & 0 & 0 & 0 & 1 & 0 & 0 & 0 & 0 & 0 & 0 & 0 & 0 \\
0 & 0 & 0 & 0 & 0 & 0 & 0 & 0 & 0 & 0 & 0 & 0 & 0 & 0 & 0 & 0 & 0 & 0 & 0 \\
0 & 0 & 0 & 0 & 0 & 0 & 0 & 0 & 0 & 1 & 0 & 0 & 0 & 0 & 0 & 0 & 0 & 0 & 0 \\
0 & 0 & 0 & 0 & 0 & 0 & 0 & 0 & 0 & 0 & 0 & 0 & 0 & 0 & 0 & 0 & 0 & 0 & 0 \\
0 & 0 & 0 & 0 & 0 & 0 & 0 & 0 & 0 & 0 & 0 & 0 & 0 & 0 & 0 & 0 & 0 & 0 & 0 \\
0 & 0 & 0 & 0 & 0 & 0 & 0 & 0 & 0 & 0 & 0 & 0 & 0 & 0 & 0 & 0 & 0 & 0 & 0 \\
0 & 0 & 0 & 0 & 0 & 0 & 0 & 0 & 0 & 0 & 0 & 0 & 0 & 0 & 0 & 0 & 0 & 0 & 0 \\
0 & 0 & 0 & 0 & 0 & 0 & 0 & 0 & 0 & 1 & 1 & 1 & 0 & 0 & 0 & 0 & 0 & 0 & 0 \\
0 & 0 & 0 & 0 & 0 & 0 & 0 & 0 & 0 & 0 & 1 & 0 & 0 & 0 & 0 & 0 & 0 & 0 & 0 \\
0 & 0 & 0 & 0 & 0 & 0 & 0 & 0 & 0 & 0 & 0 & 0 & 0 & 1 & 1 & 1 & 1 & 0 & 0 \\
0 & 0 & 0 & 0 & 0 & 0 & 0 & 0 & 0 & 0 & 0 & 0 & 0 & 0 & 0 & 0 & 0 & 0 & 0 \\
0 & 0 & 0 & 0 & 0 & 0 & 0 & 0 & 0 & 0 & 0 & 0 & 0 & 0 & 0 & 0 & 0 & 0 & 0 \\
0 & 0 & 0 & 0 & 0 & 0 & 0 & 0 & 0 & 0 & 0 & 0 & 0 & 0 & 0 & 0 & 0 & 0 & 0 \\
0 & 0 & 0 & 0 & 0 & 0 & 0 & 0 & 0 & 0 & 0 & 0 & 0 & 0 & 0 & 0 & 0 & 0 & 0 \\
0 & 0 & 0 & 0 & 0 & 0 & 0 & 0 & 0 & 0 & 0 & 0 & 0 & 0 & 0 & 0 & 0 & 0 & 0 \\
0 & 0 & 0 & 0 & 0 & 0 & 0 & 0 & 0 & 0 & 0 & 0 & 0 & 0 & 0 & 0 & 0 & 0 & 0 \\
0 & 0 & 0 & 0 & 0 & 0 & 0 & 0 & 0 & 0 & 0 & 0 & 0 & 0 & 0 & 0 & 0 & 0 & 0 \\
0 & 0 & 0 & 0 & 0 & 0 & 0 & 0 & 0 & 0 & 0 & 0 & 0 & 0 & 0 & 0 & 0 & 0 & 0
\end{array}\right]
$$




$$
\begin{aligned}
\mathbf{Z}_{\mathrm{m}} & =\left[\begin{array}{lllllllllllllllllll}
0 & 0 & 0 & 0 & 0 & 0 & 0 & 0 & 0 & 0 & 1 & 0 & 0 & 1 & 1 & 1 & 1 & 0 & 0 \\
0 & 0 & 0 & 0 & 0 & 0 & 0 & 0 & 0 & 0 & 1 & 0 & 0 & 1 & 1 & 1 & 1 & 0 & 0 \\
0 & 0 & 0 & 0 & 0 & 0 & 0 & 0 & 0 & 0 & 0 & 0 & 0 & 0 & 0 & 0 & 0 & 0 & 0 \\
0 & 0 & 0 & 0 & 0 & 0 & 0 & 0 & 0 & 1 & 1 & 0 & 0 & 1 & 1 & 1 & 1 & 0 & 0 \\
0 & 0 & 0 & 0 & 0 & 0 & 0 & 0 & 0 & 0 & 0 & 0 & 0 & 0 & 0 & 0 & 0 & 0 & 0 \\
0 & 0 & 0 & 0 & 0 & 0 & 0 & 0 & 0 & 0 & 0 & 0 & 0 & 0 & 0 & 0 & 0 & 0 & 0 \\
0 & 0 & 0 & 0 & 0 & 0 & 0 & 0 & 0 & 0 & 0 & 0 & 0 & 0 & 0 & 0 & 0 & 0 & 0 \\
0 & 0 & 0 & 0 & 0 & 0 & 0 & 0 & 0 & 0 & 0 & 0 & 0 & 0 & 0 & 0 & 0 & 0 & 0 \\
0 & 0 & 0 & 0 & 0 & 0 & 0 & 0 & 0 & 1 & 1 & 1 & 0 & 1 & 1 & 1 & 1 & 0 & 0 \\
0 & 0 & 0 & 0 & 0 & 0 & 0 & 0 & 0 & 0 & 1 & 0 & 0 & 1 & 1 & 1 & 1 & 0 & 0 \\
0 & 0 & 0 & 0 & 0 & 0 & 0 & 0 & 0 & 0 & 0 & 0 & 0 & 1 & 1 & 1 & 1 & 0 & 0 \\
0 & 0 & 0 & 0 & 0 & 0 & 0 & 0 & 0 & 0 & 0 & 0 & 0 & 0 & 0 & 0 & 0 & 0 & 0 \\
0 & 0 & 0 & 0 & 0 & 0 & 0 & 0 & 0 & 0 & 0 & 0 & 0 & 0 & 0 & 0 & 0 & 0 & 0 \\
0 & 0 & 0 & 0 & 0 & 0 & 0 & 0 & 0 & 0 & 0 & 0 & 0 & 0 & 0 & 0 & 0 & 0 & 0 \\
0 & 0 & 0 & 0 & 0 & 0 & 0 & 0 & 0 & 0 & 0 & 0 & 0 & 0 & 0 & 0 & 0 & 0 & 0 \\
0 & 0 & 0 & 0 & 0 & 0 & 0 & 0 & 0 & 0 & 0 & 0 & 0 & 0 & 0 & 0 & 0 & 0 & 0 \\
0 & 0 & 0 & 0 & 0 & 0 & 0 & 0 & 0 & 0 & 0 & 0 & 0 & 0 & 0 & 0 & 0 & 0 & 0 \\
0 & 0 & 0 & 0 & 0 & 0 & 0 & 0 & 0 & 0 & 0 & 0 & 0 & 0 & 0 & 0 & 0 & 0 & 0 \\
0 & 0 & 0 & 0 & 0 & 0 & 0 & 0 & 0 & 0 & 0 & 0 & 0 & 0 & 0 & 0 & 0 & 0 & 0
\end{array}\right] \\
\mathbf{i}_{\mathrm{P}}^{\mathrm{T}} & =\left[\begin{array}{lllllllllllllllllll}
\mathrm{T} & 0 \\
0 & 0 & 0 & 0 & 0 & 0 & 0 & 0 & 0 & 2 & 5 & 1 & 0 & 6 & 6 & 6 & 6 & 0 & 0
\end{array}\right]
\end{aligned}
$$

Az összegzett kitettségi és összegzett impakt vektorok:

$$
\begin{aligned}
& \mathbf{e}_{\Sigma}^{\mathrm{T}}=\left[\begin{array}{lllllllllllllllllll}
0 & 0 & 0 & 0 & 0 & 0 & 0 & 0 & 0 & 12 & 22 & 5 & 2 & 24 & 30 & 24 & 30 & 2 & 4
\end{array}\right] \\
& \mathbf{i}_{\Sigma}^{\mathrm{T}}=\left[\begin{array}{lllllllllllllllllll}
5 & 5 & 15 & 24 & 18 & 3 & 3 & 6 & 30 & 23 & 18 & 2 & 3 & 0 & 0 & 0 & 0 & 0 & 0
\end{array}\right]
\end{aligned}
$$

\section{KÖVETKEZTETÉSEK}

A gráf modell és az előzőekben leírt módszer felhasználásával elvégzett elemzés eredményei alapján az alábbi következtetéseket tudjuk levonni.

\section{A kitettség vektorok}

A 2. ábrán mutatott hatásvázlat felső sorban szereplő 1-9-ig jelölt blokkjaiból csak kifelé indul jel, ezért rájuk semelyik más blokk nem hat. Ezek kitettsége tehát nulla. A további blokkok kitettségét funkciónkként vizsgáljuk.

A Távolsági (ECO) üzemmódban a legnagyobb, kitettség értékkel a 15 és 17 blokkok $\left(e_{i}=9\right)$, és a14, 16 blokkok $\left(e_{i}=6\right)$ bírnak. Ez a négy blokk a hengermozgást vezérlö útváltószelepek.

Az Ügyességi (N), Gyorsulási (P), és Hiba (m) üzemmódokban a legnagyobb kitettség értékek 14-17 blokkok, a hengermozgást vezérlő útváltószelepek $\left(e_{i}=6\right)$. A 11-es számú blokknak 5 a kitettsége, ami a hengermozgás útváltószelepeinek vezérlése. Ennek a blokknak bármilyen meghibásodása kritikus rendszerhibát okoz a jármüben. 
Hiba üzemmódban a legnagyobb kitettség értékek $\left(e_{i}=3\right)$ a 15, és 17-es blokkokra jellemző.

\section{A hatásvektorok}

A vezérlő rendszer összefoglaló sematikus ábráján látható, hogy a 14-19-el jelölt blokkoknak nincs csatlakozása további blokkokkal, ezért azok befolyásolási értékei zérók $\left(i_{j}=0\right)$.

A Távolsági üzemmódban a legnagyobb befolyásolási érték az $i_{j}=5$, ami a 3-as számú blokk (lineáris helyzetérzékelő), valamint $i_{j}=6$ a 4 , és 5 blokkok (gázpedál, és nyomásszenzor 1) esetén

Ügyességi, és Gyorsulási üzemmódokban a legnagyobb befolyásolási értékek $i_{j}=6$ a 4 és 5 (gázpedál, és nyomásszenzor 1) blokkok esetén tapasztalható, illetve a 9-es számú üzemmód választó kapcsoló esetén $i_{j}=7$.

Hiba üzemmódban a legnagyobb befolyásolási értékek $i_{j}=6$ a 4-es gázpedál szenzor, valamint $i_{j}=7$ a 9-es (programválasztó kapcsoló) esetén $\left(i_{j}=0\right)$

A rendszer összegzett kitettség vektorának legnagyobb értékei, a 14, és 16 elemekre 24, a 15, és 17 elemek esetén pedig 30.

Megállapítható, hogy a hengermozgás vezérlőszelepei a vezérlőrendszer legérzékenyebb részei, vagyis a rendszer további elemeinek meghibásodása ezek funkcióit érintik a leginkább. A vezérelt rendszer funkcióját vizsgálva ezen blokkok kiesése teljes funkciókiesést okoz a rendszerben.

A nyomásirányítás funkció programkód a vezérlő kontrollerében. Itt fordítási, és kódolási hibaellenőrzés javasolt.

\section{ÖSSZEGZÉS}

A tanulmány egy könnyen használható algoritmust és alkalmazási lehetőségét mutatta be az Óbudai Egyetem PowAir pneumobil csapatának Ignite nevü jármüvének vezérlésének vizsgálatával. A kapott eredmények egyrészt igazolták a mátrixalgebrai elemző módszer alkalmazhatóságát, egyrészt hasznos információkat adott a pneumobilok vezérlő rendszereinek fejlesztéséhez.

\section{FELHASZNÁLT IRODALOM}

[1] Broinstejn, I. N. - Szemengyajev, K. A. - Musiol, G. - Mühlig, H.: Matematikai kézikönyv, Typotex, Budapest (2006).

[2] Fazekas Ferenc: Alkalmazott matematika II., egyetemi jegyzet, Tankönyvkiadó, Budapest (1979).

[3] Péter Tamás: Tetszöleges méretủ nemlineáris közúti közlekedési hálózatok modellezése speciális hálózati gráffal, amelyben a gráf csúcsai általánosított szakaszok, a gráf élei a csúcsok közötti kooperálót leíró dinamikus relációk, A jövő járműve, 3. pp. 26-29.

[4] Pokorádi László: Rendszerek és folyamatok gráfelméleti vizsgálata, Tudományos Kiképzési Közlemények, 1993/2-3, pp. 33-44.

[5] Pokorádi László: Karbantartás elmélet, DE MFK, Debrecen (2002).

[6] Pokorádi László: Rendszerek és folyamatok modellezése, Campus Kiadó, Debrecen (2008). 


\section{GRAPH MODELLING OF PNEUMATIC VEHICLE CONTROL SYSTEM}

Pneumatic drive is an alternative to alternative car protrusion. However pneumatic engine control requires an adequate control system to fulfill all the requirements of being powerful, and economic in the same time. Like in conventional cars, the engine control requires microcontroller control, which is handling sensors data, and controlling actuators, like pressure-, and directional control valves in many driving modes. Thanks to Aventics/Emerson pneumobile competition many ways of vehicle control systems have been developed since 2008, including mechanical, electro-pneumatic, PLC, relays, and so on. Adequate control systems are already available, for all these methods, but flexibility, and reliability issues are forcing us to use different approach of design in order to recognize component impacts, and exposion to other components. Using this method help us to identify the components, which require special attention to make robust, or developing fault tolerant control method to keep up vehicle functionality in case of component failure.

Keywords: vehicle; pneumobil; control system; graph modelling;

\begin{tabular}{|c|c|}
\hline $\begin{array}{l}\text { Dr. Szakács Tamás (PhD) } \\
\text { adjunktus } \\
\text { Óbudai Egyetem, } \\
\text { Mechatronikai és Jármütechnikai Intézet } \\
\text { szakacs.tamas @ bgk.uni-obuda.hu } \\
\text { orcid.org/0000-0002-7636-7488 }\end{array}$ & $\begin{array}{l}\text { Tamás Szakács Dr. (PhD) } \\
\text { lecturer } \\
\text { Óbuda University, } \\
\text { Institute of Mechatronics and Vehicle Engineering } \\
\text { szakacs.tamas@bgk.uni-obuda.hu } \\
\text { orcid.org/0000-0002-7636-7488 }\end{array}$ \\
\hline $\begin{array}{l}\text { Dr. Pokorádi László }(\mathrm{CSc}) \\
\text { egyetemi tanár } \\
\text { Óbudai Egyetem, } \\
\text { Mechatronikai és Jármütechnikai Intézet } \\
\text { pokoradi.laszlo@ bgk.uni-obuda.hu } \\
\text { orcid.org/0000-0003-2857-1887 }\end{array}$ & $\begin{array}{l}\text { László Pokorádi Dr. (CSc) } \\
\text { Full professor } \\
\text { Óbuda University, } \\
\text { Institute of Mechatronics and Vehicle Engineering } \\
\text { pokoradi.laszlo@bgk.uni-obuda.hu } \\
\text { orcid.org/0000-0003-2857-1887 }\end{array}$ \\
\hline
\end{tabular}

A kutatást a Magyar Állam és az Európai Unió támogatásával, az Európai Szociális Alap társfinanszírozásával megvalósuló EFOP-3.6.2-16-2017- 00016: „Autonóm járművek dinamikája és irányítása az automatizált közlekedési rendszerek követelményeinek szinergiájában” projekt támogatta.

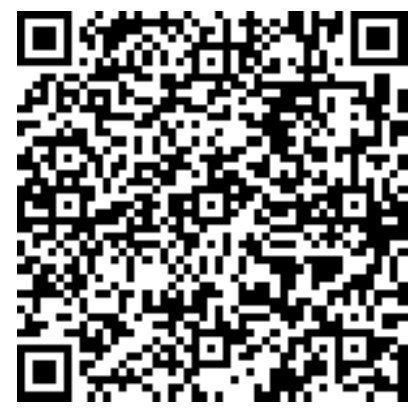

http://journals.uni-nke.hu/index.php/reptudkoz/article/view/263/34 